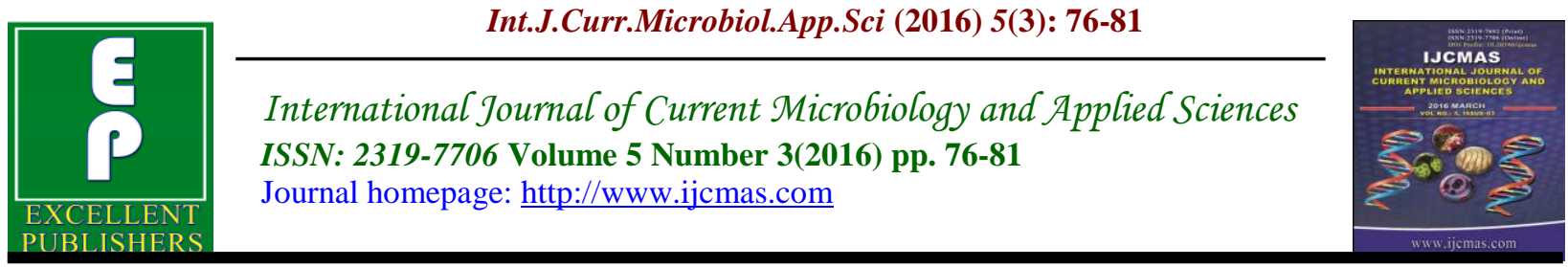

Original Research Article

http://dx.doi.org/10.20546/ijcmas.2016.503.011

\title{
Toxic Effect of Lindane on Male Reproductive Cells in Mammals
}

\author{
Priyanka Mehta* \\ Division of Standardization, IVRI, Bareilly U.P. India \\ *Corresponding author
}

\begin{abstract}
A B S T R A C T
Keywords

Toxic Effect of

Lindane,

Male Reproductive

Cells

Article Info

Accepted:

08 February 2016

Available Online:

10, March 2016

Present investigation gives the effects of lindane in steroidogenesis and testis tissues of adult male albino rat. Adult male rats were orally administered with lindane at a dose of $6.0 \mathrm{mg} / \mathrm{kg}$ body weight per day for 30 days, the rat were operated to remove one testis from each, for histopathological studies. Male albino rats were treated with lindane, decreased the testes parameters, protein, cholesterol and total lipid. A histopathological analysis of testicular tissue from treated rats showed cell disorganization. Cells were irregularly shaped, with marked intercellular space between the spermatogenic cells were observed. Our results imply that organochlorine insecticides like lindane can cause reproductive disorders, and therefore more attention should be directed towards understanding the affects of persistent pesticide residues on reproductive outcomes.
\end{abstract}

\section{Introduction}

Lindane, also known as gamma-hexachlorocyclohexane, $(\gamma-\mathrm{HCH}), \quad$ gammaxene, Gammallin and benzene hexachloride (BHC). It is an organochlorine chemical variant of hexachlorocyclohexane that has been used to treat food crops and to forestry products, as a seed treatment, a soil treatment, and to treat livestock and pets. It has also been used as pharmaceutical treatment for lice and scabies, formulated as a shampoo or lotion $(12,13,14)$ Lndane is a neurotoxin that interferes with GABA neurotransmitter function by interacting with the $\mathrm{GABA}_{\mathrm{A}}$ receptor-chloride channel complex at the picrotoxin binding site.

In humans, lindane affects the nervous system, liver and kidneys, and may well be acarcinogen (5.6). It is unclear whether lindane is an endocrine disruptor $(7,8,9)$. The lindane is widely used as a pesticide in many countries (7). Lindane ( hexachlorocyclohexane) is an organochlorine insecticide that is still employed for various purposes, including both human and veterinary medicine and as agriculture and horticulture pesticide (1). Lindane may be taken up cutaneously (2) or orally from contaminated food $(3,4)$ Even though the symptoms of chlorinated hydrocarbon toxicity convulsion and other (5) are evidence that chlorinated hydrocarbons exert physiological effects by their interaction with components of the nervous system, the mechanism of action of the insecticide lindane is still poorly 
understood. Lindane has been reported to induce reproductive abnormalities in male rat and induction of stress to play an important role in the toxicity. Lindane and other pesticide are released into the environment intentionally and exposure to such pesticide interacts with the mammalian endocrine system and may cause adverse effect on reproductive function in mammals and human (6). Lindane posses lipophilic character and enter into the food chain resulting in bioaccumulation in the body tissue (9) blood and breast milk of human and animal. Lindane alter the activity of some membrane bound protein $(10,11)$. Lindanes interfere with peripheral and central nerve conduction inducing neurotoxic effect $(12,13)$. Lindane has been shown to decrease rodent sexual receptive (14) and a possible activity at the level of steroid hormone balance in female rats has been described (15). Lindane is a lipophilic compound that can be accommodated in lipid bilayers (19) and this accommodation could induce a variation in membrane fluidity by modifying the cholesterol content. Biological events such as transformation, growth, cell cycle and differention (20) as well as modification in the accessibility to some hormone receptor (21) or the activities of certain enzymes (22, 23) have been shown to be accompanied by alteration in membrane fluidity. Lindane has been reported to cause impairment to many biological functions, including reproduction in humans and animals. It has adverse effects on various hormone dependent reactions in the male reproductive system. The testes have been found to be highly sensitive target organs for lindane, which has been shown to disrupt testicular morphology $(26,27,28,29)$ and induce epididymal cellular degeneration (30). It causes alterations in Leydig and Sertoli cells and impairs their functions $(31,32)$. Investigations have revealed that exogenous lindane treatment diminishes serum testosterone level, and it has been confirmed that lindane acts as an inhibitor on testicular steroidogenesis $(33,34)$. This study was conducted to examine the effects of lindane on male reproductive parameters related to hormones and lipid profile of testis and plasma.

\section{Materials and Methods}

Animals Male albino rat (10-12 weeks of age) were obtained from Indian Veterinary Research Institute Bareilly (U.P). The rats were reared in plastic cages and maintained under a well regulated light and dark (12h12h) schedule with normal room temperature during whole work. The food and water were ad libitum.

\section{Experimental Design}

The rats are divided into two groups:

1st group: Served as a control which received normal food and water.

2nd group: is treated with lindane at a dose of $6 \mathrm{mg} / \mathrm{kg}$.

After 30 days of treatment animals were operated and testes was kept at $-20 \mathrm{c}$ for biochemical study(40, 41, 42, 43). For Histopathological studies, testis of each rat was fixed in Bouins fluid passed through xylene and embedded in paraffin wax tissues were sectioned at the thickness of $5 \mu \mathrm{m}$ and stained with haematoxylene and eosin. Spermatogenesis was observed in $100 \mathrm{x}$.

Statistical Analysis: SD for six rats \pm Values were expressed as mean in the each group and statistical significant differences between mean values were determined by one way analysis of variance (ANOVA). The results were statistically analyzed by 
Graphpad Instat Software version 3 was used and $\mathrm{p}<0.05$ was considered to be significant.

\section{Results and Discussion}

Abnormal spermatogenesis due to Lindane: Semineferous tubules are cleaved, sertoli cells are affected as a result spermatogenesis is affected. Junction between the tubules is affected $(29,30,31)$ Histopathology of albno rat testis Sertoli cells are normal Junction between tubules are normal Seminiferous tubules are normal (Fig 1). Sertoli cells are affected due to lindane effect in testis. There is breakage in junction between tubules seminiferous tubules are cleaved due to toxicity of lindane (Fig 2).

Treatment of lindane at $6 \mathrm{mg} / \mathrm{kg}$ for 30days cause the decreased level of lipid, \& protein in testes. It may be due to the lipid peroxidative damage caused by lindane. Cholesterol is the precursor for synthesis of steroid hormones and its decreased level in testes indicates the direct effect of lindane on Leutinizing hormone (LH)and testosterone. Many chemicals, such as pesticides, industrial chemicals, plastics, plasticizers, pharmaceuticals and others present in the environment, have been shown to cause disruptive endocrine effects, yet currently, for many of them, there is no known structure/ function relationship (24). Like other persistent organic pollutants, lindane can enter the food chain and lipophylicity facilitates its accumulation in the various tissues of living organisms where, after absorption and distribution, it can easily reach the essential tissues of the reproductive system (25).

Table.1 Effect of Lindane on Testis Parameters of Experimental Rats

\begin{tabular}{|l|l|l|l|}
\hline S.No. & PARAMETERS & CONTROL & LINDANE TREATED \\
\hline 1 & Protein $(\mathrm{mg} / \mathrm{g})$ & $123.55 \pm 0.45$ & $116.25 \pm 0.28^{*}$ \\
\hline 2 & & & \\
\hline 3 & Cholestrol $(\mathrm{mg} / \mathrm{g})$ & $14.806 \pm 0.073$ & $14.892 \pm 0.33^{*}$ \\
\hline
\end{tabular}

Fig.1 Showing Normal Testes

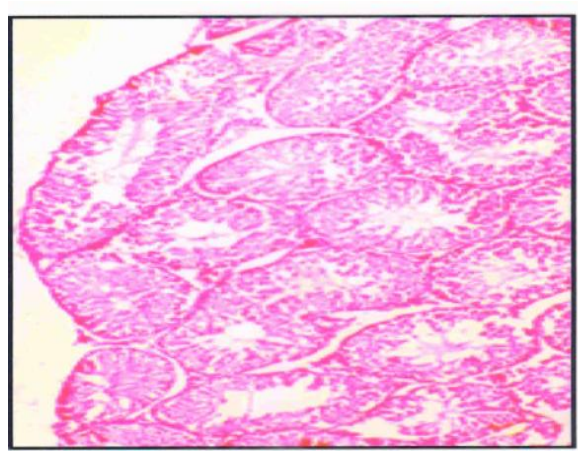


Fig.2 Shows Lindane Exposed Testes

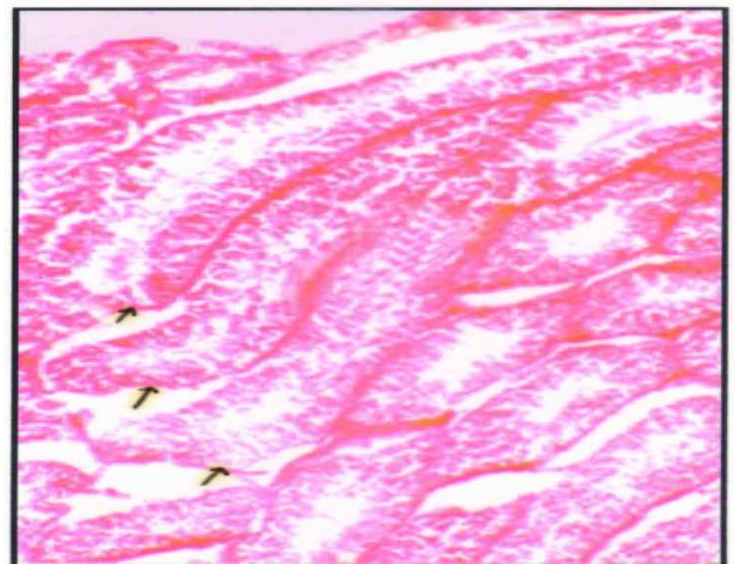

It is generally accepted that testosterone is converted into $5 \alpha$-reduced metabolites, which interact with their specifi c receptors to become fully active $(35,36)$. Both in vitro and in vivo lindane exposure interfere with androgen metabolism and with the formation of a $5 \alpha$ - dihydrotestosterone receptor complex in the prostate of rats (37, 38) as the consequences of exposure to lindane. Seminiferous tubules and Leydig cells degenerated during treatment with doses of $5 \mathrm{mg} \mathrm{kg-1}$ daily, over a 30-day period (54). The atrophy of somniferous tubules carrying necrosis spermatogenic cells was observed after lindane-treatment. Testicular tissue was analyzed morphologically by light microscopy (Fig. 1). In the lindane-treated rats, the cells were irregularly shaped and there was marked intercellular space between the spermatogenic cells. Spermatogenesis was still present, but cell disorganization was found. According to the present results and previously published reports $(49,29)$ much more attention should be paid to the possible effects of environmentally persistent pesticides, even if they are banned in most developed countries, in view of the fact that they may induce changes at the cellular level to crucial stages in the reproductive processes.

\section{Acknowledgement}

I am thankful to IVRI, Bareilly U.P for constant support in this work.

\section{References}

1. Wolley, D., et al. 1985. Exoxidation of the lindane metabolite. Neurotoxicol., 6: 165-192.

2. Lange, M., et al. 1981. Role of lindane in membrane. Dermatol., 271: 387-399.

3. Solomon, L.M., et al. 1977. Gama benzene hexachloride toxicity. Dermatol., 113: 353-357.

4. Saxena, M.C., et al. 1981. Acute high dose toxicity affect the central nervous system. Toxicol., 48: 127-134.

5. Matsumura, F., et al. 1975. Modes of action of insecticides. Toxicol. insecticides., Plenum press, New York.

6. Carreror, I., et al. 1989. Biochem. Biophys. Res. Comm., 158: 1391-11396.

7. Wolley, D., et al. 1985. Effect of lindane type insecticide in mammals. Neurotoxicol., 6: 165-192.

8. Fitz loff, Pans, J.F., 1984. Influence of lindane on the fluidity of rat ventral prostrate. Xenobio., 599-604.

9. FAO/WHO. 2002. Joint meeting of the FAO panel of expert on pesticide 
residues in food and the environment and the WHO core Assessment group Rom.

10. Carreror, I., et al. 1989. Biochem. Biophys. Res. comm., 158: 1391-11396.

11. Pulido, J.A. 1990. Lindane alter modification to membrane lipid structure. Life sci., 47: 0099-1107.

12. Wolley, D., et al. 1985. Effect of lindane type insecticides. Neurotoxicol., 6: 165192.

13. Joy, R.M. 1982. Mode of action in central nervous system. Neurobehav. Toxicol., 4: 813-823.

14. Uphouse. L. 1987. Overall evalution of carcinogenicity. Toxicol., 4: 7-14.

15. Chadwick, R.W., et al. 1985. Enhanced pesticide metabolism. Biochem. Toxicol. 3: 147-158.

16. Patel, A.H., et al. 1985. Regulation of expression of steroidogenic enzyme in leydig cell. Biol. Reprod., 52: 217-225.

17. Lopez, P., et al. 1988. Pest. Biochem BiophyActa., 812: 731-739.

18. Gutierrez, M.T., et al. 1989. Influence of lindane on the fluidity of rat ventral prostrate. Biochem. BiophyActa., 1003: 67-71.

19. Autunes-Maderia, M.C., et al. Effect of membrane fluidity and activity of membrane bound protein. 820: 165-172.

20. Cheng, S., et al. 1979. Influence of lindane on the fluidity of rat ventral prostrate. Arch. Biochem. Biophy., 196: 424-429.

21. Deve, J.R., et al. 1984. Biochem. BiophyActa., 772: 321- 327.

22. Shinitzky, M., et al. 1984. In Physiology of membrane fluidity. Vol. 1, pp 1-15.

23. Hebdon, G.M., et al. 1980. Biochemical properties of harmones. 78: 120-123.

24. Diamanti-Kandarakis, E., et al. 2009. Endocrine-Disrupting Chemicals: An Endocrine Society Scientific Statement. Endocrine Reviews, 30(4): 293-342.
25. Dalsenter, P.R., et al. 1997. Serum testosterone and sexual behavior in rats after prenatal exposure to lindane. Bull. Environ. Contam. Toxicol., 59: 360-366.

26. Dikshith, et al. 1978. Histopathological and biochemical changes in guinea pigs after repeated dermal exposure to benzene hexachloride. Toxicol., 10: 5566.

27. Chowdhury, S., et al. 2007. Fuzzy approach for selection of drinking water disinfectants. J. Water SRTAqua., 56(2): 75-93.

28. Dalsenter, P.R., et al. 1996. Reproductive toxicity and tissue concentrations of lindane in adult male rats. Hum. Exp. Toxicol., 15: 406-410.

29. Srinivasan, K., et al. 1998. Changes induced by hexachlorocyclohexane isomers in rat liver and testis. Bull. Environ. Contam. Toxicol., 41: 531-539.

30. Chowdhury, A.R., et al. 1994. Lindane induced changes in rat epididymis. Ind. J. Physiol. Allied Sci., 48: 179- 183.

31. Suwalsky, M., et al. 2000. Plasma absorption and ultrastructural changes of rat testicular cells induced by lindane. Hum. Exp. Toxicol., 19: 529-533.

32. Saradha, B., et al. 2008. Lindane alters the levels of HSP70 and clusterin in adult rat testis. Toxicol., 243: 116-123.

33. Walsh, L.P., et al. 2000. Effects of lindane on steroidogenesis and steroidogenic acute regulatory protein expression. Biol. Reprod., 63: 10241033.

34. Ronco, A.M., et al. 2001. The mechanism for lindaneinduced inhibition of steroidogenesis in cultured rat Leydig cells. Toxicol., 159: 99-106.

35. Kniewald, Z., et al. 1971. Studies on the biosynthesis of testosterone in the rat. Acta. Endocrinol., 68: 614-624. 
36. Milkovic, S., et al. 1974. The effect of collagenase from rat testis. F. Reprod. fert., 36: 161-167.

37. Simic, B., et al. 1991. Reversibility of the inhibitory effect of atrazine and lindane on cytosol 5adihydrotestosterone receptor complex formation in rat prostate. Bull. Environ. Contam. Toxicol., 46: 92-99.

38. Simic, B., et al. 1992. Testosterone metabolism and formation of cytosol $5 \alpha$ dihydrotestosterone-receptor complex in rat prostate in vitro: effects of lindane and malathion. Toxic., 6: 267-271.

39. Alford, F.P., et al. 1951. Temporal parrerns of circulating harmones as assessment by continuous blood. Acta. Endo., 20: 42-51.

40. Lowry, O.H., et al. 1951. Protein measurement with Folin phenol reagent. 193: 265-275.

41. Werner, et al. 1918. Ultramicrodetermination of serum triglycerides of serum trigycerides by bioluminescent assay. Clin.Ch.,

42. Allian, C.C., et al. 1970. Enzmatic estimation of cholesterol. Clin. chem., 20: 268-271.

43. Zilvermit, D.B. 1950 Jan. Micro determination of plasma phospholipids by trichloroacetic acid and precipitation. J. lab. clin. Med., 35(1): 155-160.

44. Payne, A.H., et al. 1995. Regulation of expression of steroidogenic leydig cell. Biol.Reprod., 52: 217-2.

45. Russell, D., et al. 1977. Desmosomelike junctions between Sertoli and germ cells in the rat testis. 148: 301-312.
46. Roosen-Runge, E.C. 1977. The process of spermatogenesis in animals. Cambridge University Press, Cambridge, pp 12-14.

47. Chowdhury, A.R., et al. 1974. Steroidogenic impairment after lindane treatment in male rat. VOI.16.

48. Russell, L.D., et al. 1990. Histological and histopathological evaluation of the testis. Cache River, Cleanvater.

49. Prasad, A.K., et al. 1995. Effect of dermal application of hexachlorocyclohexane $(\mathrm{HCH})$ on male reproductive system of rat. Hum. Exp. Toxicol. 14: 484-488.

50. Pant, N., et al. 2007. Chlorinated pesticide concentration in semen of fertile and infertile men and correlation with sperm quality. Environ. Toxicol. Pharmacol., 23: 135-139.

51. Silvestroni, L., et al. 1999. Effect of organochlorine xenobiotics on human spermatozoa. Chemosphere, 39: 12491252.

52. Dikshith, T.S.S., et al. 1978. Comparative response of male rats to parathion and lindane: Histopathological and biochemical studies. Environ. Res., 17: 1-9.

53. Srinivasan, K., et al. 1988. Changes induced by hexachlorocyclohexane isomers in rat liver and testis. Bull. Environ. Contam. Toxicol., 41: 531-539.

54. Chowdhury, A.R., et al. 1987. Testicular changes of rats under lindane treatment. Bull. Environ. Contam. Toxicol., 38: 154-156. Source of support: Nil; Conflict of interest: None declared.

\section{How to cite this article:}

Priyanka Mehta. 2016. Toxic Effect of Lindane on Male Reproductive Cells in Mammals. Int.J.Curr.Microbiol.App.Sci. 5(3): 76-81. doi: http://dx.doi.org/10.20546/ijcmas.2016.503.011 